University of Michigan Law School

University of Michigan Law School Scholarship Repository

Law \& Economics Working Papers

$4-1-2014$

From Here to Eternity: The Folly of Perpetual Trusts

Lawrence W. Waggoner

University of Michigan Law School, waggoner@umich.edu

Follow this and additional works at: https://repository.law.umich.edu/law_econ_current

Part of the Estates and Trusts Commons, Law and Economics Commons, Public Law and Legal

Theory Commons, and the Tax Law Commons

Working Paper Citation

Waggoner, Lawrence W., "From Here to Eternity: The Folly of Perpetual Trusts" (2014). Law \& Economics Working Papers. 76.

https://repository.law.umich.edu/law_econ_current/76

This Article is brought to you for free and open access by University of Michigan Law School Scholarship Repository. It has been accepted for inclusion in Law \& Economics Working Papers by an authorized administrator of University of Michigan Law School Scholarship Repository. For more information, please contact mlaw.repository@umich.edu. 


\title{
From Here to Eternity: The Folly of Perpetual Trusts
}

\author{
Lawrence W. Waggoner ${ }^{*}$
}

I. The Perpetual-TRust Movement AND Its Genesis. . . . . . . . . 1

II. MOVInG DOWN THE GENERATIONAL LADDER, STEP BY STEP. . . . . 4

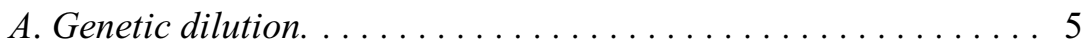

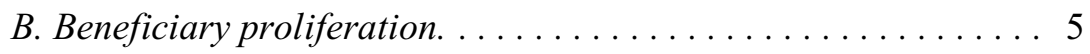

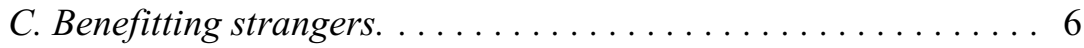

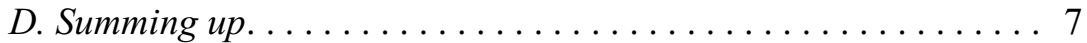

III. OTHER CONCERNS. . . . . . . . . . . . . . . . . . . . . . . 10

A. Rising management costs.................. 10

B. Trust document obsolescence.................. 12

C. Trustee turnover.. . . . . . . . . . . . . . . . . . 13

IV. THE AMERICAN LAW INSTITUTE DECLARES THE PERPETUAL-TRUST

MOVEMENT "ILL ADVISED"... . . . . . . . . . . . . . . . . . . . 14

V. CONGRESS SEEMS DECIDEDLY UNINTERESTED IN FIXING

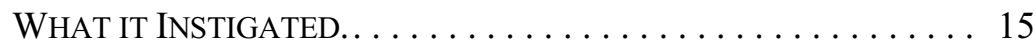

\section{THE PERPETUAL-TRUST MOVEMENT AND ITS GENESIS}

Trusts that can operate for as many as a thousand years or even forever, typically for the benefit of the settlor's descendants living from time to time, now and in the future, are all the rage in banking and estate-planning circles. And the wealthy are responding by creating them. Why? Are the state legislators who vote to authorize perpetual trusts and the wealthy who create them thinking through what they are allowing or putting in place? I have doubts.

Before 1986, the wealthy had little incentive and probably little desire to establish perpetual trusts, even though they were permitted to do so under the law of Wisconsin, South Dakota, or Idaho. ${ }^{1}$ So, what happened in 1986? That was when Congress passed the federal

Lewis M. Simes Professor Emeritus of Law, University of Michigan; Reporter, Restatement (Third) of Property: Wills and Other Donative Transfers. Although parts of this essay are drawn from the Restatement, the essay itself has not been submitted to or approved by the American Law Institute.

1 See Max M. Schanzenbach \& Robert H. Sitkoff, Perpetuities or Taxes? Explaining the Rise of the Perpetual Trust, 27 CARdozo L. Rev. 2465, 2466-68 (2006). 
Law \& Economics W orking Papers, Art. 76 [2014]

generation-skipping transfer tax (GST tax). ${ }^{2}$ The GST tax imposes a flat tax at the highest federal estate tax rate on generation-skipping transfers. The purpose of the GST tax is to make sure that property is taxed every time it shifts from generation to generation or skips a generation. $^{3}$

The GST exemption, ${ }^{4}$ not the GST tax itself, sparked the perpetual-trust movement..$^{5}$ As its name implies, the GST exemption allows settlors to create trusts that are exempt from the GST tax. As of 2014, the ceiling on the exemption is $\$ 5.34$ million (twice that for a married couple). ${ }^{6}$ When Congress granted the exemption, it did not impose a durational limit on exempt trusts. Congress relied on state perpetuity laws to supply that limit. The reliance on state perpetuity laws was badly misplaced. At the instigation of state banking groups

2 I.R.C. $\S \S 2601-2663$.

${ }^{3}$ There are three types of generation-skipping transfers subject to the GST tax (unless exempted): taxable terminations, taxable distributions, and direct skips. See I.R.C. § 2611.

In general, a taxable termination occurs when an interest in trust property terminates, unless immediately after the termination, a non-skip person has an interest in the property or at no time after the termination may a distribution be made from the trust to a skip person. See I.R.C. 2612(a). For example, in a trust to pay income to or for the benefit of the settlor's daughter, $D$, for life, then principal to $D$ 's children (the settlor's grandchildren), the termination of $D$ 's life interest would be a taxable termination. See Treas. Reg. § 26.26121(f) Ex. (4).

A taxable distribution occurs when income or principal is distributed from a trust to a skip person. See I.R.C. 2612(b). Thus, for example, in a trust to pay the income to or for the benefit of the settlor's son, S, for life, with a direction to pay half of the principal to S's child, GC, when GC reaches age 35, the distribution of half of the principal to GC on GC's 35th birthday would be a taxable distribution. See Treas. Reg. § 26.2612-1(f) Ex. (10).

A direct skip occurs when an interest in property is transferred to a skip person in a manner that is subject to the federal gift tax or federal estate tax. See I.R.C. § 2612(c). A skip person is defined in I.R.C. $\S 2613$ as (1) a natural person assigned to a generation that is two or more generations below the generation assignment of the transferor or (2) a trust if all interests in the trust are held by skip persons or if there is no person holding an interest in the trust and at no time after the transfer may a distribution be made from the trust to a nonskip person. Thus, for example, a gift to a grandchild would be direct skip. See Treas. Reg. $\S 26.2612-1$ (f) Ex. (1).

${ }^{4}$ I.R.C. $\S 2631$.

${ }^{5}$ See Schanzenbach \& Sitkoff, supra note 1 passim.

${ }^{6}$ The ceiling on the GST exemption is coordinated with the ceiling on the estate and gift tax exemption and was set at \$5 million in 2010. The increase to \$5.34 million resulted from an inflation adjustment that took effect at the beginning of 2012.

Various estate-planning techniques can be used to leverage the amount exempted beyond the exemption's ceiling. See Ray D. Madoff, Immortality and the Law: The Rising Power of The American Dead 62-63 (2010); Iris J. Goodwin, How the Rich Stay Rich: Using a Family Trust Company to Secure a Family Fortune, 40 Seton HaLl L. ReV. 467, 492 (2010). A GST-exempt trust retains its exemption no matter how much the trust's post-creation value appreciates above the maximum exemption amount. 
and estate-planning attorneys, ${ }^{7}$ states began to pass legislation allowing transferors to create perpetual trusts - trusts that can last for several centuries ${ }^{8}$ or even forever. ${ }^{9}$

Congress and state legislative bodies have therefore combined to set the perpetual-trust movement in motion. Although Congress did not intend to do so, whereas the state legislative bodies acted deliberately, the primary responsibility still rests with Congress. By creating, albeit inadvertently, a tax advantage for trusts that can remain tax exempt for centuries, Congress is the legislative body that facilitated the movement.

Because Congress has not yet acted to rectify its mistake, the perpetual-trust movement is in full bloom. With state perpetuity laws out of the way, the wealthy are creating perpetual trusts in significant numbers. ${ }^{10}$ An empirical study found that roughly $\$ 100$ billion in trust assets had flowed into states allowing perpetual trusts. ${ }^{11}$ The study was based on data through 2003 from the annual reports that

\footnotetext{
7 See Edward J. McCaffery, The Dirty Little Secret of (Estate) Tax Reform, 65 StAn. L. REV. ONLINE 21, 26 (2012), available at http://ssrn.com/abstract=2129309 ("Who benefits [from perpetual trusts]? .... [A] very large class of trust companies and other financial intermediaries."); Schanzenbach \& Sitkoff, supra note 1, at 2479-80; Joel C. Dobris, Changes in the Role and the Form of the Trust at the New Millennium, or, We Don't Have to Think of England Anymore, 62 ALB. L. REV. 543, 572 (1998) ("When the bankers want something, they get it.").

8 One-thousand years in Colorado, Utah, and Wyoming; 500 years in Arizona; 365 years in Nevada; 360 years in Alabama, Florida, and Tennessee.

${ }^{9}$ Alaska, Delaware, District of Columbia, Idaho, Illinois, Maine, Maryland, Michigan, Missouri, Nebraska, New Hampshire, New Jersey, North Carolina, Ohio, Pennsylvania, Rhode Island, South Dakota, Virginia, and Wisconsin.

${ }^{10}$ Charitable trusts, by contrast, have traditionally been allowed to operate in perpetuity (and many do), but charitable trusts are subject to two safeguards that make the perpetuity tolerable: (1) the public benefit standard and (2) judicial modification under cy pres when circumstances cause the settlor's design to become outmoded. See RESTATEMENT (THIRD) OF TRUSTS § 28 (2003).

11 See Robert H. Sitkoff \& Max Schanzenbach, Jurisdictional Competition for Trust Funds: An Empirical Analysis of Perpetuities and Taxes, 115 YALE L.J. 356, 410 (2005). The study found that the states that attracted the most perpetual-trust business were those that do not tax trust income produced by funds originating from out of state. See id. States that levy an income tax on trust funds attracted from out of state experienced no observable increase in trust business. See id. at 420 .

The $\$ 100$ billion trust figure did not represent the value of GST-exempt perpetual trusts. It appears that the payoff for institutional trustees operating in these perpetual-trust states is that "high net worth clients" create perpetual trusts up to the GST exemption limit and also move the greater bulk of their wealth into non-exempt trusts with the same institutional trustee. See MADOFF, supra note 6, at 80-82 (noting that "Congress created a marketing bonanza for banks and trust companies" and that perpetual trusts have "been tremendously profitable for banks and other financial service companies, which can generate large fees administering these long term trusts.").
} 
institutional trustees file with federal banking authorities. Considerably more wealth has undoubtedly moved into these states in the years following 2003. ${ }^{12}$ Moreover, the $\$ 100$ billion figure undercounts the actual value of trust assets flowing into these states, because the sources on which the study was based were reports from federal regulatory agencies. ${ }^{13}$ These reports contain no data on trusts in which the trustee is a family trust company, organized under state law for the limited purpose of administering trusts of one family. Family trust companies, which are becoming popular vehicles for administering perpetual trusts of the very wealthy, ${ }^{14}$ are regulated if at all by state law, ${ }^{15}$ not federal law, and consequently do not report to federal agencies.

\section{MOVING DOWN THE GENERATIONAL LADDER, STEP BY STEP}

I ask again: Are the state legislators who vote to authorize perpetual trusts and the wealthy who create them thinking through what they are allowing or putting in place? The perpetual trusts that are now in existence are only in their first or second decade, so experience with them as they continue past the boundary set by traditional perpetuity law is lacking. Nevertheless, some projections can be made, since the prototypical perpetual trust is a discretionary trust for the benefit of the settlor's descendants from time to time living forever (or for several centuries). ${ }^{16}$

12 Writing in 2011, the year after Congress raised the exemption to $\$ 5$ million (see supra note 6), Michael Graetz noted that the increase prompted the wealthy to move even more assets into perpetual trusts: "I know of more than $\$ 1$ billion in New York City alone." Michael J. Graetz, The Politics and Policy of the Estate Tax-Past, Present, and Future 11 (Yale Law \& Economics Research Paper No. 425, 2011), available at http://papers.ssrn.co,/sol3/papers.cfm?abstract_id=1755161. From 1990 to 1991, Professor Graetz served as Deputy Assistant Secretary for Tax Policy in the Treasury Department. See also Wilmington Trust, A Window of Opportunity: Harnessing the Power of A Delaware Dynasty TRUST, https:/www.wilmingtontrust.com/repositories/ wtc_sitecontent/PDF/Window_of_Opportunity.pdf(last visited Aug. 17, 2012) ("Using the increased exemptions to fund a trust, particularly a Delaware Dynasty Trust, can be a great way to benefit future generations.").

13 See Sitkoff \& Schanzenbach, supra note 11, at 387-88.

14 See Goodwin, supra note 6, at 467-68 (noting that family trust companies are generally thought to be appropriate only for families with a net worth of at least $\$ 200$ million). See also Alan V. Ytterberg \& James P. Weller, Managing Family Wealth Through a Private Trust Company, 36 ACTEC L.J. 623, 631-32 (2010).

${ }^{15}$ See Goodwin, supra note 6, at 474-75 (noting that family trust companies are lightly regulated by state law in some states and unregulated by state law in other states).

16 See Richard W. Nenno, Delaware Dynasty Trusts, Total Return Trusts, and Asset Protection Trusts 182-84 (2006). 
A. Genetic dilution. With each step down the generational ladder, the settlor's genetic relationship with the descendant-beneficiaries will decline rather precipitously. On average, and disregarding nongenetic descendants such as adoptees, a settlor's genetic relationship with his or her descendants is cut in half at each succeeding generation. At the 14th generation (i.e., the generation born about 300 years after the settlor's death), the settlor's genetic relationship is reduced to about 0.0061 per cent, which - due to our common origins - is about the same relationship one has with any randomly selected member of the population. ${ }^{17}$

$B$. Beneficiary proliferation. As the settlor's genetic relationship with the beneficiaries diminishes, the number of descendantbeneficiaries will proliferate geometrically. ${ }^{18}$ One hundred and fifty years after creation, a perpetual trust could have about 450 living beneficiaries; after 250 years, more than 7,000 living beneficiaries; after 350 years, about 114,500 living beneficiaries. ${ }^{19}$ This means that

${ }^{17}$ See John H. Beckstrom, Sociobiology and Intestate Wealth Transfers, 76 Nw. U. L. Rev. 216, 232-33 (1981), citing, at 233, Richard Dawkins, The SElFish Gene 100 (1976). See also Alina Dizik, Not Your Grandmother's Genealogy Hobby, WALl St. J., Dec. 1, 2011, at D3 ("If you go back far enough, you're probably connected [genetically] to everyone you know.").

${ }^{18}$ For simplicity, and because there appears to be no empirical evidence on point, the projections in the text disregard the possibility of two descendants of the settlor having children together, in a marital relationship or otherwise. To the extent that two of the settlor's descendants have children together, the geometric proliferation of the settlor's descendants will be dampened, because each pair of parents will, in effect, occupy the place of one descendant in the family tree. Take, for example, two distant cousins. Although they are both descendants of the settlor, they might or might not know that and therefore might or might not know that they are related to one another. If they have children together, they will only have two children on average rather than two each, and the dampening effect will cascade down the affected descending lines. Moreover, the dampening effect will be greater the earlier it happens and the more often it happens. Although marriage between first cousins is prohibited in about half of the states (see Wikipedia, Cousin Marriage Law in the United States by State, http://en.wikipedia.org/wiki/Cousin_marriage_law_in_the_United_States_ by_state (last visited Jan. 21, 2012)), marriage between more distant relatives is not prohibited. The phenomenon of two relatives having children together also affects the proliferation of ancestors, as described in Wikipedia, Pedigree Collapse, http://en.wikipedia.org/wiki/Pedigree_collapse (last visited Jan. 21, 2012). Although the phenomenon discussed in this footnote could lead to fewer beneficiaries than projected in the text, another phenomenon - increased longevity, resulting in four or more generations living at any one time - cuts the other way. See infra note 25. My thanks to Howard Helsinger for pointing out to me the possibility of two descendants of the settlor having children together.

${ }^{19}$ The projections are based on the following averages: life expectancy of 75 years, two children per couple, and 25-year separation between generations. The projections are also based on the assumption that the trust was created when the settlor had two children and four grandchildren. 
Law \& Economics W orking Papers, Art. 76 [2014]

350 years after creation, Michigan Stadium or the Rose Bowl would not be large enough to hold them all. The beneficiaries, each with standing to bring a lawsuit against the trustee for violation of any of the trustee's fiduciary duties, would have to book Rungrado May Day Stadium in Pyongyang North Korea or Salt Lake Stadium in Kolkata India if they were to get together for a meeting. ${ }^{20}$

Disputes seem inevitable. A trustee operates under a strict duty to distribute trust funds only to those persons who qualify as beneficiaries under the terms of the trust. A trustee also operates under the duty of impartiality. In discharging the duty of impartiality, "a trustee will often find it desirable, and sometimes important or even necessary, to consult with beneficiaries and obtain information from them concerning their financial needs and circumstances and perhaps their preferences concerning matters of trust administration." 21

C. Benefitting strangers. As the trust drifts deeper and deeper into its second and third centuries and beyond, and long after the settlor and the attorney responsible for proposing and drafting the trust have passed away, the beneficiaries will, to be sure, share a common ancestor, but their common ancestor will be very remote and they will have branched into thousands of individual three- or four-generation families basically unaware of their relationship with all but the closest of the other branches. Readers of this essay can be expected to know

In Jesse Dukeminier \& James E. Krier, The Rise of the Perpetual Trust, 50 U.C.L.A. L. REV. 1303, 1339 (2003), the authors greatly underestimate the growth of the number of beneficiaries. They say that there will only be 16 beneficiaries after 100 years. Like the projections in the text above, they assume two children per family. Under that assumption, the only way that such a trust could only have 16 beneficiaries after 100 years - assuming they mean 100 years after the settlor's death-would be if they only count the senior generation. In point of fact, three or more generations of descendants are likely to be living at the same time, all of whom are permissible recipients of income and/or corpus, which makes them beneficiaries of the trust. Consequently, 100 years after the settlor's death, there are likely to be at least 16 living members of the senior generation, 32 living members of the middle generation, and 64 living members of the junior generation-112 beneficiaries in all.

20 See Wikipedia, List of Stadiums by Capacity, http://en.wikipedia.org/wiki/ List_of_stadiums_by_capacity (last visited Oct. 17, 2011).

${ }^{21}$ Restatement (ThiRd) OF Trusts $\S 79 \mathrm{cmt}$. d (2007). For more on trustee duties and risks of liability regarding perpetual trusts, see 3 RESTATEMENT (THIRD) OF PROPERTY: Wills AND OTHER DONATIVE Transfers at pp. 558-60 [hereinafter Property RESTATEMENT]. Note also that the Uniform Trust Code, in a bracketed provision, requires the trustee to notify all qualified beneficiaries of an irrevocable trust who have attained 25 years of age of the existence of the trust, the identity of the trustee, and their right to require trustee's reports, and provides that this duty of notification cannot be overridden by the terms of the trust. See UnIf. TRust Code $\S 105(b)(3)$ (2010); Thomas P. Gallanis, The Trustee's Duty to Inform, 85 N.C. L. REV. 1595 (2007). 
their brothers and sisters (at least those of the whole blood ${ }^{22}$ ) and their descendants, probably their first cousins and their descendants, and possibly even their second cousins and some or all of their descendants. But few would know or know of their third or fourth cousins (descendants of their great-great-grandparents or of their great-great-great-grandparents), let alone the tens of thousands of their remote relatives in more distant branches.

Whether or not politics still makes strange bedfellows, ${ }^{23}$ perpetual trusts certainly do. Imagine a perpetual trust in which the more-than100,000 living beneficiaries include President Barack Obama and his descendants and former President George H.W. Bush and his descendants (including former President George W. Bush). Or, a perpetual trust in which the more-than-100,000 living beneficiaries include President Obama and his descendants, former Vice President Richard Cheney and his descendants, and the living descendants of former President Harry S. Truman. Both trusts would exist and still be operating today if Samuel Hinckley, who died in Massachusetts in 1662, had created a perpetual trust for his descendants and if Mareen Duvall, who died in Maryland in 1694, had created a perpetual trust for his descendants. ${ }^{24}$

D. Summing up. The following table projects a settlor's descending line through the twentieth generation and depicts the number of descendants and their genetic relationship to the transferor at each generational level. The number of living beneficiaries is calculated by adding the number of descendants born in a generation

\footnotetext{
${ }^{22}$ In an age of multiple marriages and other formal and informal multiple relationships, some might not know or know of all of their half brothers and sisters.

23 The maxim that politics makes strange bedfellows was coined by the American essayist Charles Dudley Warner (1829-1900).

${ }^{24}$ The distant relationships between President Obama and former Presidents Bush and Truman and former Vice-President Cheney were first chronicled on the website of the New England Historic Genealogical Society, http://www.newenglandancestors.org/ about/7320.asp (last visited Aug. 2, 2009; website no longer available) (print copy on file with author). The website also noted that other distant relatives of President Obama include the following deceased individuals and their descendants: President Gerald R. Ford (common ancestor: Joseph Holley, who died in Massachusetts in 1647); President Lyndon B. Johnson (common ancestor: Philip Ament, who died in Kentucky in 1836); President James Madison, Jr. (common ancestor: Edwin Conway, who died in Virginia in 1675); British Prime Minister Sir Winston Churchill (common ancestor: George Allen, who died in Massachusetts in 1648); and Confederate General Robert E. Lee (common ancestor: Richard Eltonhead, who died in Lancashire, England, after 1664). Information regarding the ancestry of all American presidents is collected in GARY BOYD ROBERTS, ANCESTORS OF AMERICAN PRESIDENTS (2009).
} 
to the number of descendants born in the two prior generations. ${ }^{25}$ For example, the projection of about 114,500 living beneficiaries 350 years after the trust is created is calculated by adding the number of descendants born in the 16 th generation $(65,536)$ to the number of descendants born in the 15 th generation $(32,768)$ and in the 14 th generation $(16,384)$. The assumption is that 350 years after the trust is created, there will be about 16,384 living members of the senior generation, about 32,768 living members of the middle generation, and about 65,536 living members of the youngest generation, all of whom would be beneficiaries of a discretionary trust to distribute income or principal or both to or for the benefit of the settlor's descendants living from time to time. ${ }^{26}$

\begin{tabular}{|l|l|c|c|c|}
\hline $\begin{array}{c}\text { Gener- } \\
\text { ation }\end{array}$ & $\begin{array}{c}\text { Settlor's Descendants Projected } \\
\text { Through the 20th Generation }\end{array}$ & $\begin{array}{c}\text { Number of } \\
\text { Years } \\
\text { Born After } \\
\text { Settlor's } \\
\text { Death }\end{array}$ & $\begin{array}{c}\text { Number of } \\
\text { Descendants } \\
\text { Per } \\
\text { Generation }\end{array}$ & $\begin{array}{c}\text { Genetic } \\
\text { Relationship } \\
\text { to Settlor }\end{array}$ \\
\hline 1 st & Children & $\begin{array}{c}\text { Settlor } \\
\text { Alive }\end{array}$ & 2 & $50 \%$ \\
\hline 2nd & Grandchildren & $\begin{array}{c}\text { Settlor } \\
\text { Alive }\end{array}$ & 4 & $25 \%$ \\
\hline 3rd & Great-grandchildren & 25 & 8 & $12.5 \%$ \\
\hline 4th & Great-great-grandchildren & 50 & 16 & $6.25 \%$ \\
\hline 5th & Great-great-great-grandchildren & 75 & 32 & $3.125 \%$ \\
\hline 6 th & $\begin{array}{l}\text { Great-great-great-great- } \\
\text { grandchildren }\end{array}$ & 100 & 64 & $1.5625 \%$ \\
\hline
\end{tabular}

25 Although the possibility of two relatives having children together in a descending line will dampen the geometric proliferation of descendants (see supra note 18), the conservative assumption that only three generations of descendants will be living at any one time cuts the other way. Even today, four-generation families are increasingly common, and if, as expected (see, e.g., SONIA ARRISON, 100 Plus: How THE COMING AgE OF LONGEVITY Will Change Everything 21-47 (2011)), longevity increases over the next several centuries, five- or maybe six-generation families might become common. Assuming that all the other assumptions (such as the number of children per family and the 25-year interval between generations) remain the same, the existence of four-, five-, or even six-generation families would cause the number of living beneficiaries at any one time to be greater than projected.

${ }^{26}$ Some model perpetual-trust documents incorporate an escape clause in the form of a nongeneral power of appointment granted to each descendant-beneficiary to appoint his or her share of trust principal outright to his or her descendants. See, e.g., NENNO, supra note 16 , at 164 . If a perpetual trust contains such a nongeneral power, the size of the remaining trust assets and the number of beneficiaries projected above will be reduced to the extent that one or more beneficiaries actually exercises his or her nongeneral power. 


\begin{tabular}{|c|c|c|c|c|}
\hline 7th & $\begin{array}{l}\text { Great-great-great-great-great- } \\
\text { grandchildren }\end{array}$ & 125 & 128 & $0.78125 \%$ \\
\hline 8th & $\begin{array}{l}\text { Great-great-great-great-great-great- } \\
\text { grandchildren }\end{array}$ & 150 & 256 & $0.390625 \%$ \\
\hline 9th & $\begin{array}{l}\text { Great-great-great-great-great-great- } \\
\text { great-grandchildren }\end{array}$ & 175 & 512 & $0.1953125 \%$ \\
\hline 10th & $\begin{array}{l}\text { Great-great-great-great-great-great- } \\
\text { great-great-grandchildren }\end{array}$ & 200 & 1,024 & $0.0976562 \%$ \\
\hline 11th & $\begin{array}{l}\text { Great-great-great-great-great-great- } \\
\text { great-great-great-grandchildren }\end{array}$ & 225 & 2,048 & $0.0488281 \%$ \\
\hline 12 th & $\begin{array}{l}\text { Great-great-great-great-great-great- } \\
\text { great-great-great-great- } \\
\text { grandchildren }\end{array}$ & 250 & 4,096 & $0.024414 \%$ \\
\hline 13th & $\begin{array}{l}\text { Great-great-great-great-great-great- } \\
\text { great-great-great-great-great- } \\
\text { grandchildren }\end{array}$ & 275 & 8,192 & $0.012207 \%$ \\
\hline 14 th & $\begin{array}{l}\text { Great-great-great-great-great-great- } \\
\text { great-great-great-great-great-great- } \\
\text { grandchildren }\end{array}$ & 300 & 16,384 & $0.0061035 \%$ \\
\hline 15 th & $\begin{array}{l}\text { Great-great-great-great-great-great- } \\
\text { great-great-great-great-great-great- } \\
\text { great-grandchildren }\end{array}$ & 325 & 32,768 & $0.0030517 \%$ \\
\hline 16 th & $\begin{array}{l}\text { Great-great-great-great-great-great- } \\
\text { great-great-great-great-great-great- } \\
\text { great-great-grandchildren }\end{array}$ & 350 & 65,536 & $0.0015258 \%$ \\
\hline 17 th & $\begin{array}{l}\text { Great-great-great-great-great-great- } \\
\text { great-great-great-great-great-great- } \\
\text { great-great-great-grandchildren }\end{array}$ & 375 & 131,072 & $0.0007629 \%$ \\
\hline 18th & $\begin{array}{l}\text { Great-great-great-great-great-great- } \\
\text { great-great-great-great-great-great- } \\
\text { great-great-great-great- } \\
\text { grandchildren }\end{array}$ & 400 & 262,144 & $0.0003814 \%$ \\
\hline 19th & $\begin{array}{l}\text { Great-great-great-great-great-great- } \\
\text { great-great-great-great-great-great- } \\
\text { great-great-great-great-great- } \\
\text { grandchildren }\end{array}$ & 425 & 524,288 & $0.0001907 \%$ \\
\hline 20th & $\begin{array}{l}\text { Great-great-great-great-great-great- } \\
\text { great-great-great-great-great-great- } \\
\text { great-great-great-great-great-great- } \\
\text { grandchildren }\end{array}$ & 450 & $1,048,576$ & $0.0000953 \%$ \\
\hline
\end{tabular}

Is the beneficiary proliferation projected above inevitable? Some model perpetual-trust documents incorporate an "escape clause" in the form of a nongeneral power of appointment granted to each descendant-beneficiary or perhaps to the senior member of each branch to distribute his or her share of trust principal outright to his 
Law \& Economics W orking Papers, Art. 76 [2014]

or her descendants (or perhaps to a broader group of permissible appointees). ${ }^{27}$ For tax reasons, these powers must be nongeneral, meaning that the powerholder cannot withdraw assets for his or her own benefit. ${ }^{28}$ Because it is impossible to predict how often these powers exist and will actually be exercised, the most that can be said is that the number of beneficiaries projected above will be reduced to the extent that one or more beneficiaries exercises the power. ${ }^{29} \mathrm{~A}$ deterrent to exercise is that any exercise constitutes a partial termination of the trust, and the amounts the powerholder directs to be distributed to his or her descendants or other permissible appointees lose the tax umbrella of the GST exemption. Note also that the typical perpetual trust is a discretionary trust, so escape clauses pose a potential source of dispute and possible litigation: determining a powerholder's exact share of principal. Each exercise or partial exercise requires a recalculation of the powerholder's share and poses a potential source of litigation over the accuracy of the recalculation. Calculations and recalculations are not likely to be problematic in the first few generations, but are likely to become more and more disputable the deeper down the generational ladder the trust goes as the family divides into hundreds and then thousands of branches.

\section{OTHER CONCERNS}

Genetic dilution and beneficiary proliferation are not the only concerns associated with perpetual trusts. ${ }^{30}$ Other concerns include rising management costs, trust document obsolescence, and trustee turnover.

A. Rising management costs. As these trusts continue to operate

27 See, e.g., NENNO, supra note 16, at 183.

28 See I.R.C. $\S \S 2041,2514$. Powers are nongeneral if the powerholders cannot distribute assets to themselves, their estates, their creditors, or the creditors of their estates. See Property Restatement, supra note 21, 17.3 ; Unif. Powers of Appointment Act $\S 102$ (2013). For rules governing the exercise of a nongeneral power, see PROPERTY Restatement, supra note 21, § 19.14; Unif. Powers of ApPointment ACt $§ 305$ (2013).

29 One of the architects of the perpetual-trust movement cautions against exercise: "[G]etting assets out of a trust is as easy as getting toothpaste out of a tube, while putting assets back into a trust is as difficult as trying to get toothpaste back into the tube." Garrett Moritz, Note, Dynasty Trusts and the Rule Against Perpetuities, 116 HARV. L. REV. 2588, 2605 (2003) (Jan. 9, 2003, telephone interview by Moritz with Jonathon G. Blattmachr).

${ }^{30}$ Lucy Marsh has written that the genetic dilution and beneficiary proliferation should "in [themselves], demonstrate the foolishness of Dynasty Trusts." See Lucy A. Marsh, The Demise of Dynasty Trusts: Returning the Wealth to the Family, 5 Est. Plan. \& CMTY.Prop. L.J. 23, 50 (2012-2013). 
beyond and then far beyond the traditional perpetuity boundary of about a century, the costs of trust administration could become significant and be a drag on performance. As the settlor's descending line divides and redivides into hundreds and then thousands of branches, the trustee would have to employ and assign more and more trust officers, each with primary operational responsibility - aided by ever-advancing technologies - for a manageable number of branches. The terms of the trust might attempt to anticipate this problem by providing that the original trust be divided and redivided into subtrusts or separate shares, perhaps as each member of the senior generation of a branch dies. If the terms of the trust do not so provide, the original trust would by necessity have to be divided and redivided defacto into multiple sub-trusts or separate shares. Still another possibility is for the fiduciary to exercise a "decanting power" to divide and redivide the trust into sub-trusts. ${ }^{31}$ Because the aggregate number of beneficiaries of all of the sub-trusts or shares would equal the number of beneficiaries of a single trust, the result would constitute a change in form only and, in any event, would not slow down the severe genetic dilution that occurs with the birth of each new generation.

Just as disputes seem inevitable concerning the identity of the beneficiaries, ${ }^{32}$ they also seem inevitable concerning the proper manner of the hundreds and maybe thousands of divisions, redivisions, and re-redivisions that the trustees will have to make over the centuries. Ironically, as trust administration becomes more and more cumbersome and litigation prone, the trustees themselves - whose long-deceased and forgotten predecessors had

${ }^{31}$ A "decanting power" is a fiduciary power of appointment endemic in discretionary trusts that allows the trustee - without judicial oversight — to modify the terms of the original trust by creating a new trust with different terms. Under the Property Restatement, the holder of a "decanting power" cannot exercise the power beyond its scope and the holder's exercise is subject to fiduciary obligations. See PROPERTY RESTATEMENT, supra note $21, \S 17.1 \mathrm{cmt}$. g; § 19.14 cmts. f \& g(4); § 19.15; Morse v. Kraft, 468 Mass. 92, 95 (2013) (citing the Property Restatement $\S 17.1 \mathrm{cmt}$. g with approval); Lawrence W. Waggoner, What's in the Third and Final Volume of the New Restatement of Property That Estate Planners Should Know About, 38 ACTEC L.J. 23, 40-41 (2012). See also Restatement (ThIRD) OF TRUSTS $\S 50$ (2003). The Treasury Department and the IRS are considering the tax consequences of some of the more aggressive uses of the "decanting power" under non-uniform "decanting" statutes. See IRS Notice 2011-101, http://www.irs.gov/pub/irs-drop/n-11-101.pdf (last visited Jan. 8, 2012). The Uniform Law Commission is currently working on a uniform trust decanting act. See Unif. TRust Decanting Act (now in draft form), http://www.uniformlaws.org/Committee.aspx?title=Trust\%20Decanting.

${ }^{32}$ See supra note 21 and accompanying text. 
lobbied so hard to capture the perpetual-trust business - might find it necessary to mount an effort to change current trust law by lobbying state legislatures to grant them the power to modify or terminate the trusts or by petitioning state courts to modify or terminate them. ${ }^{33}$

B. Trust document obsolescence. State-of-the-art perpetual-trust documents of today are considered modern, sophisticated, and up-todate. ${ }^{34}$ Will those documents be looked upon as modern, sophisticated, and up-to-date centuries from now? Consider the devices used centuries ago by English landowners to control family estates through subsequent generations. Such devices, which were then considered modern, sophisticated, and up-to-date, first took the form of the unbarrable entail and, after the entail became barrable, the strict settlement. ${ }^{35}$ These devices and the terminology associated with them became obsolete long ago. If the past is any guide to the future, an early 21 st century perpetual-trust document will seem as obsolete to those in distant centuries as a 17th century document appears to us today. ${ }^{36}$ Moreover, a perpetual-trust document drafted today will often

${ }^{33}$ See Dukeminier \& Krier, supra note 19, at 1339-42. Trustees might seek to apply the doctrine of equitable deviation, which authorizes a court to modify the terms of a trust if, due to circumstances not anticipated by the settlor, the modification will further the purposes of the trust. See Restatement (THIRD) OF TRUSTS $§ 66$ (2003) (unanticipated circumstances); UNIF. TRUST CODE $\S 412$ (unanticipated circumstances). Whether the equitable-deviation doctrine can be used to modify a perpetual trust has yet to be decided. Alternatively, trustees might seek to extend the charitable trust doctrine of cy pres (see supra note 10) to private trusts. See Restatement (ThIRD) OF Trusts $\S 67$ (2003) (cy pres); Unif. TRUST CODE $\S 413$ (cy pres). Trustees might also use a "decanting power" (see supra note $31)$ to shorten the duration of the trust.

${ }^{34}$ For a model perpetual-trust document, see, e.g., NENNO, supra note 16, at 182-94.

${ }^{35}$ See, e.g., Lloyd Bonfield, Marriage Settlements 1601-1740: The Adoption OF the Strict Settlement (1983); John Habakkuk, Marriage, Debt, and The Estate SYSTEM: ENGLISH LANDOWNERSHIP 1650-1950, at 1-5, 17, 36, $46-47$ (1994);A.W.B. Simpson, Legal TheOry and Legal History: Essays on the COMMON LAW 143-62 (1987) (contrasting the English and Scottish entails); J.H. BAKER \& S.F.C. MILSON, SOURCES of English; EILEen Spring, Law, LAND AND Family: Aristocratic InHERitance in ENGLAND, 1300 TO 1800 (1993).

${ }^{36}$ Ruth Deech also notes how the passage of time can make a trust document obsolete: "If a settlor or testator had total liberty to dispose of his property among future beneficiaries, the recipients, being fettered by his wishes, would never enjoy that same freedom in their turn. The liberty to make fresh rearrangements of assets is necessary not only in order to be rid of irksome conditions attached by earlier donors to the enjoyment of income but also in order to be able to manoeuvre in the light of new tax laws, changes in the nature of the property and in the personal circumstances of the beneficiaries, unforeseeable by the bestintentioned and most perspicacious of donors." Ruth Deech, Lives in Being Revived, 97 LAW Q. REV. 593, 594 (1981). Some of the obsolescence problems Deech points to, especially the tax problems, might be cured today by the exercise of a "decanting power" (see Diana S.C. Zeydel \& Jonathan G. Blattmachr, Tax Effects of Decanting-Obtaining and Preserving the Benefits, 111 J. TAX'N 288 (Nov. 2009)), or by judicial modification (see PROPERTY 
define the class of descendants according to time-of-creation standards, standards that run the serious risk of becoming out of date as concepts of family change over time. No trust drafted in 1650 or earlier could have contained provisions anticipating the possibility of adopted children, ${ }^{37}$ children of assisted reproduction, or children born to a surrogate mother, much less second-parent adoptions or posthumously conceived children. Likewise, no perpetual-trust document drafted today will be able to anticipate concepts of family and descent as they change and adjust over the next several centuries.

C. Trustee turnover. Another matter that should be of concern to the wealthy who create perpetual trusts is what entity is going to serve as trustee over these vast intervals? In an era in which banks and other financial institutions go out of business, merge, or are taken over by other banks or financial institutions, ${ }^{38}$ the bank or financial institution originally selected will not likely continue in anything like its present form for the next 200 years, 300 years, or for eternity. Over vast intervals such as these, the identity, location, capabilities, and expertise of the trustee will likely change many times over. Trustee turnover is enough of a problem for a trust whose duration is within the traditional perpetuity limit of about a century. The problem will be far more acute for a trust spanning several centuries or lasting forever. As the beneficiaries grow into the tens of thousands and divide into thousands of branches mostly unknown to one another, the personnel and technology necessary to administer a trust with fifteen or fewer beneficiaries (two children, four grandchildren, and as many as eight great-grandchildren) will not look anything like the personnel and technology necessary to manage a trust with 100,000 or more beneficiaries. Settlors should be aware that the trustees will become much different entities than the ones they initially entrusted with their fortunes.

Settlors should also be aware that the trustees, whether they are or are not the ones initially entrusted with their fortunes, will have the

Restatement, supra note 21, 12.2 (2003); Unif. Trust Code $§ 416$; Unif. Probate CODE $\S 2-806)$.

37 Adoption was first authorized in England in 1926. See Adoption of Children Act 1926. In the United States, adoption began to be authorized in the mid-19th century. See E.W. CARP, FAmily Matters: SeCrecy And Disclosure in the History of Adoption 11 (1998)

${ }^{38}$ According to SNL Financial, "[m] ore than a dozen trust companies were swallowed by bigger institutions [in 2011]." Robin Sidel, A Family Loses Its Faith in Trust, WALL ST. J., March 22, 2012, at C3. 
Law \& Economics W orking Papers, Art. 76 [2014]

power to modify the terms of the original trust through what has come to be known as the "decanting power." 39

\section{THE AMERICAN LAW INSTITUTE DECLARES THE PERPETUAL- TRUST MOVEMENT “ILL ADVISED”}

The traditional limit on dead-hand control of a life in being plus 21 years allows trusts or other property arrangements to continue for about a century, ${ }^{40}$ which is an extraordinarily long period of time. Writing more than four decades ago, W. Barton Leach cautioned settlors and their lawyers against using the full perpetuity period:

I hasten to add that the wisdom of tying up property for anything like a century is quite another matter. Any lawyer whose wisdom is equal to his skill would surely advise against any such attempt. Such a lawyer could point out that it would have been utterly impossible for any testator dying in 1866 to foresee the events that have taken place in the succeeding century, and ... any prediction as to what may occur in the century following 1966 would be even more unlikely to conform to reality. ${ }^{41}$

Regarding the wisdom of allowing property to be tied up, not for a "mere" century, but for several centuries and maybe forever, it is worth noting that the American Law Institute recently declared the perpetual-trust movement "ill advised." 42

39 See supra note 31.

40 The Property Restatement adopts a different approach to perpetuities: With certain qualifications and exceptions, the Restatement requires a trust to terminate no later than the death of the youngest beneficiary who is no more than two generations younger than the settlor. See PROPERTY RESTATEMENT, supra note 21, at $\S \S 27.1$ to 27.3. The objective is not to produce a materially longer or shorter maximum period, but to tailor the period to the individual trust and family circumstances. See id. at 569-70. See also Lawrence W. Waggoner, The American Law Institute Proposes a New Approach to Perpetuities: Limiting the Dead Hand to Two Younger Generations (Univ. of Mich. Pub. Law Working Paper No. 200, 2010), available at http://ssrn.com/abstract $=1614936$.

${ }^{41}$ W. Barton Leach, Property LaW Indicted! 71 (1967).

42 The members of the Institute discussed the perpetual-trust movement at their 2010 annual meeting and voted unanimously to adopt the following statement: "It is the considered judgment of the American Law Institute that the recent statutory movement allowing the creation of perpetual or near-perpetual trusts is ill advised." See ProPERTY Restatement, supra note 21, at 564; Lawrence W. Waggoner, Curtailing Dead-Hand Control: The American Law Institute Declares the Perpetual-Trust Movement Ill Advised (Univ. of Mich. Pub. Law Working Paper No. 199, 2010), available at http://ssrn.com/abstract=1614934. Mark Ascher was more blunt: He described the movement as "loony." Mark L. Ascher, But I Thought the Earth Belonged to the Living, 89 TEX. L. Rev. 1149, 1160 (2011) (reviewing Lawrence M. Friedman, Dead Hands: A Social 
I ask for the third time, this time in a slightly different way: If the foregoing projections and other concerns had been before them, would the state legislators still have been convinced that it is good public policy to authorize perpetual trusts, and would the wealthy still have been convinced that the tax advantages are worth putting them in place $?^{43}$ The farther a perpetual trust moves in time beyond the traditional perpetuity boundary of about a century, the more the trust will become little more than one for thousands upon thousands of strangers, not only to the long-deceased settlor but also mostly to each other. $^{44}$

\section{CONGRESS SEEMS DECIDEDLY UNINTERESTED IN FIXING WHAT IT INSTIGATED}

Although it is worth asking whether, if the foregoing projections and other concerns had been before them, the state legislators would still have been convinced that it is good public policy to authorize perpetual trusts, and whether the wealthy would still have been convinced that the tax advantages are worth putting them in place, the primary responsibility for the perpetual-trust movement rests with Congress and the primary responsibility for curtailing it also rests with Congress.

Congress, however, seems decidedly uninterested in correcting its earlier mistake of relying on state perpetuity law to curtail the

History OF Wills, TRUSTS, AND INHERITANCE (2009)).

${ }^{43}$ For a defense of perpetual trusts and a criticism of this essay, see Bridget $\mathrm{J}$. Crawford, Who Is Afraid of Perpetual Trusts?, 111 Mich. L. REV. FIRST IMPRESSIONS 79 (2012). It bears noting that when Professor Crawford was in private practice with a large New York City law firm, she and a co-author praised what they called the "power of the new perpetual trusts now permissible under Alaska law" and promoted them "for wealthy US citizens and non-US persons holding substantial US real property or stock." See Jonathan G. Blattmachr \& Bridget J. Crawford, Wilderness No More: Alaska as the New "Offshore" Trust Jurisdiction, Amicus CuRIAE 30, 30 (Nov. 1999), available at http://journals.sas.ac.uk/amicus/article/view/1424 (last visited Aug. 17, 2012).

I see no reason to respond separately to Crawford's Who Is Afraid article. This essay itself refutes her arguments, as does the discussion of perpetual trusts at the 2010 annual meeting of the American Law Institute, supra note 42.

${ }^{44}$ As Ascher concluded, "in the final analysis, the only real beneficiaries will be trustees and the lawyers," adding: "Is it any wonder that elements of the financial-services industry lobbied so hard for the necessary legislation?" Ascher, supra note 42, at 1161.

McCaffery noted: "The rich setting up dynasty trusts are willing to pay their advisers for the privilege of avoiding transfer taxes forever. Those advisers and financial intermediaries, in turn, are willing to pay Congress to keep the fear of a death tax - and hence their lucrative business model—alive (forever). Congress is happy to cash the checks." He concludes: "On the estate tax, then, it is easy to predict what will happen: not much." See McCaffery, supra note 7, at 26. 
duration of GST-exempt trusts. On February 26, 2014, the House Ways and Means Committee unveiled its long-awaited proposal for comprehensive tax reform, ${ }^{45}$ but the proposal neglects to address the GST exemption for perpetual trusts. So does the Senate Finance Committee's Draft of the Tax Technical Corrections Act of 2014. ${ }^{46}$ Thanks to Congressional indifference, the perpetual-trust movement remains alive and well. ${ }^{47}$

45 Tax Reform Act of 2014 (Discussion Draft), H.R., 113 ${ }^{\text {th }}$ Cong., 2d Sess., http://waysandmeans.house.gov/uploadfiles/statutory_text_tax_reform_act_of_2014_disc ussion_draft_022614.pdf.

$46 \quad$ See http://www.finance.senate.gov/imo/media/doc/Chairman $\% 27 \mathrm{~s} \% 20$ Mark\%20-\%20Technical\%20Corrections.pdf.

47 In a companion article, I have proposed a solution that would effectively end the perpetual-trust movement and its associated perpetual GST exemption for both new and existing trusts and that is consistent with the original intent of Congress in enacting the GST exemption. See Lawrence W. Waggoner, Congress Promotes Perpetual Trusts: Why?, (Univ. of Mich. Pub. Law \& Legal Theory Research Paper No. 349, last updated May 2014), available at http://ssrn.com/abstract=2326524. 